\title{
Effect of Plant Growth Regulators on Seed Germination in Walla Patta (Gyrinops walla)
}

\author{
K.P.S.S. Dharmasena and K.K.I.U. Arunakumara*
}

Department of Crop Science, Facultyof Agriculture, University of Ruhuna, Mapalana, Kamburupitiya, Sri Lanka

\section{Correspondence:}

*kkiuaruna@crop.ruh.ac.lk,

(iD https://orcid.org/0000-0002-57081-0215

DOI: http://doi.org/10.4038/sljae.v2i2.38

\begin{abstract}
Walla patta (Gyrinops walla Gaertn.) belongs to family Thymelaeaceae, is a valuable endemic plant in Sri Lanka. Recently, this species has become a topic of wide interest due to its ability to produce highly valuable agarwood resin. Commercial cultivation of the species is yet to start, thus natural habitats are tremendously under pressure due to illegal harvest. The seeds of $G$. walla are recalcitrant and loose the viability within a shorter period of time. Due to the limited availability of information, the present study was aimed at evaluating the effect of plant growth regulators on seed germination. The experiment was conducted in a protected plant house at the Faculty of Agriculture, University of Ruhuna from September 2019 to January 2020. A completely randomized design (CRD) was used with three replicates. The influence of gibberellic acid ( $\left.\mathrm{GA}_{3}\right)$, indole-3-acetic acid (IAA), and indol-3-butyric acid (IBA) at $800 \mathrm{ppm}, 1000 \mathrm{ppm}$, and $1200 \mathrm{ppm}$ concentrations on seed germination of the $G$. walla were investigated. Seeds soaked in nine different hormone solutions for 24 hours were placed in disinfected sand media and germinations were recorded daily up to 60 days. Seeds treated with water served as the control. Final germination percentage, mean germination time, mean daily germination, germination rate index and average time taken to start the germination were recorded. Hormone treatments except IBA at $1000 \mathrm{ppm}$, significantly increased $(p<0.05)$ the seed germination, when compared with the control. $\mathrm{GA}_{3}$ at 1200 ppm showed the highest (65\%) germination followed by IAA at $1000 \mathrm{ppm}(53.33 \%)$ and $800 \mathrm{ppm} \mathrm{(50 \% ).} \mathrm{GA} \mathrm{G}_{3}$ treatments showed a significantly $(p<0.05)$ faster germination rate than IAA and IBA. Based on the results, $\mathrm{GA}_{3}$ at $1200 \mathrm{ppm}$ can be recommended to enhance the seed germination of G. walla.
\end{abstract}

Keywords: Gibberellic acid (GA3), Gyrinops walla, Indole-3-acetic acid (IAA), Indole-3butyric acid (IBA), Seed germination 


\section{Introduction}

Walla patta (Gyrinops walla), belongs to family Thymelaeaceae is a valuable plant endemic to Sri Lanka. It is known as "Sri Lankan Agar". The $G$. walla tree grows up to $15 \mathrm{~m}$ height with small, rounded crown and distributed in the lower elevations of wet and intermediate zones in Sri Lanka (Subasinghe 2013; Alwis et al. 2016). With the discovery of highly valuable resin called "agarwood", the species has gained amplified attention (Alwis et al. 2016; Mohamed and Lee 2016). Dark colour resin agarwood (Subasinghe and Hettiarachchi 2015) is found to form in the heartwood of certain genera (Aquilaria, Gyrinops, Aetoxylon, and Gonystylus) of the Thymelaeaceae family as a self-defence mechanism (Alwis et al. 2019) in response to biotic and abiotic stresses (Singh and Sharma 2015). Agarwood is widely used as therapeutic perfumes, traditional medicine, and aromatic food ingredient and for religious purposes (Liu et al. 2013). The attractive aroma of agarwood, which receives high ritual and social significance in Asian, Indian, and Middle Eastern cultures, is released once the piece of heartwood is gently burnt (Alwis et al. 2019). Gyrinops genera has eight species including $G$. walla, which is the only species naturally found in Sri Lanka (Alwis et al. 2016).
The agarwood resin produced in G. walla is chemically similar to that of produced by Aquilaria species (Subasinghe et al. 2012; Mohamed and Lee 2016), thus the species gained high recognition among traders and consumers. The best quality agarwood is generally guaranteed a price over US\$ 30,000 per $\mathrm{kg}$, thus placed among the most expensive natural raw materials in the world (Subasinghe 2013; Abdin 2014). The annual global market for agarwood is estimated to be increased steadily (Akter et al. 2013). Illegal harvesting of $G$. walla from natural habitats is frequently reported as commercial plantations are yet to be established. Due to limited natural distribution of the species and overexploitation, there is a high threat on natural stock of $G$. walla. Convention on International Trade in Endangered Species of Wild Fauna and Flora (CITES) has listed Gyrinops and Aquilaria species under Appendix II for the conservation (Mohamed and Lee 2016).

G. walla mainly propagated by seeds which, in fact, is the most reliable method of propagation. However, the seeds of $G$. walla show low natural germination as observed by the present study, which might be due to rapid decline of viability after shedding from the trees. As stated by Alwis et al. (2016), who studied the effect of storage time on 
germination and concluded that $G$. walla seeds cannot be stored for a long period. Plant growth regulators (PGRs) have been widely employed in enhancing seed germination of many crops (Unal 2013; Han and Yan 2015; Vishal and Kumar 2018). External application of PGRs to seeds could enhance seed germination and seedling establishment of many aromatic and medicinal plants (Ali et al. 2010; Gholami et al. 2013; Singh et al. 2014). The present study was carried out to investigate the effect of gibberellic acid ( $\left.\mathrm{GA}_{3}\right)$, indole-3-acetic acid (IAA), and indol-3-butyric acid (IBA) on seed germination of $G$. walla.

\section{Materials and Methods}

\section{Seed collection}

Mature fruits were collected from fifteen well grown G. walla plants in Yagirala forest located in the low country wet zone of Sri Lanka. Seeds collection was done in September 2019. The length and width of fruits of five samples having randomly selected 100 fresh fruits were measured using a vernier caliper. The fresh weight of selected fruits was also measured using an electronic balance (model BS 1100H+).

Collected fruits were placed on trays and kept under room temperature until rupturing. Prior to treatment application, the length and diameter of seeds of five samples each contained randomly selected 100 seeds were measured for using a vernier caliper. Similarly, the seed weight was also measured using an electrical balance. Uniform seeds were screened and randomly selected five samples each contained 20 seeds were tested for viability using Tetrazolium test.

\section{Treatments and experimental design}

The experiment was conducted in a protected plant house at the Faculty of Agriculture, University of Ruhuna, from September 2019 to February 2020. A Completely Randomized Design (CRD) with three replicates was used. Analytical grade gibberellic acid ( $\left.\mathrm{GA}_{3}\right)$, indole3-acetic acid (IAA), and indol-3-butyric acid (IBA) were used in preparing 800 ppm, 1000 ppm and 1200 ppm concentrations. Which were based on similar studies (RojasAre'chiga et al. 2011; Guney et al. 2017). Seeds were soaked in relevant hormone solution ( $\mathrm{T}_{1}$ - IAA at $800 \mathrm{ppm}, \mathrm{T}_{2}-\mathrm{IAA}$ at $1000 \mathrm{ppm}, \mathrm{T}_{3}-$ IAA at $1200 \mathrm{ppm}, \mathrm{T}_{4}-$ IBA at $800 \mathrm{ppm}, \mathrm{T}_{5}-\mathrm{IBA}$ at $1000 \mathrm{ppm}, \mathrm{T}_{6}-\mathrm{IBA}$ at $1200 \mathrm{ppm}, \mathrm{T}_{7}-\mathrm{GA}_{3}$ at $800 \mathrm{ppm}, \mathrm{T}_{8}-\mathrm{GA}_{3}$ at $1000 \mathrm{ppm}, \mathrm{T}_{9}-\mathrm{GA}_{3}$ at $1200 \mathrm{ppm}$ ), containing a fungicide (Captan 75\% WP @ 1.5 g a.i $\mathrm{L}^{-1}$ ) for 24 hours. Similarly, seeds soaked in water with added fungicide were used as the control $\left(\mathrm{T}_{10}\right)$. 
Preparation of seed trays and seed sowing

Germination trays were filled with disinfected sand (Thiram 75\% WP @ 1.5 g a.i $\mathrm{Kg}^{-1}$ sand) and seeds were sown by placing tail-like structure above the medium following the method described by Alwis et al. (2016). Seeds were allowed to germinate under 50\% shade. Trays were irrigated twice a day and a fungicide (Captan 75\% WP @ $1.5 \mathrm{~g}$ a.i L-1) was sprayed as necessary to avoid fungal contamination.

\section{Data collection}

Germinations were recorded daily up to 60 days. Seeds with about $2 \mathrm{~mm}$ protruding radicle were considered as germinated.

At the end of the germination period, the final germination percentage (FGP), mean germination time (MGT), germination rate index (GRI), mean daily germination (MDG) were calculated using equations below (Aravind et al. 2019).

$F G P=\frac{\text { Number of germinated seeds }}{\text { Total number of seeds sown }} \times 100$

$M G T=\frac{\sum_{i=1}^{k} N_{i} T_{i}}{\sum_{i=1}^{k} N_{i}}$

Where;

$T_{i}=$ Time from the start of the experiment to the $i^{\text {th }}$ observation,
$\mathrm{N}_{\mathrm{i}}=$ Number of seeds germinated in the $\mathrm{i}^{\text {th }}$ time (not the accumulated number, but the number corresponding to the $i^{\text {th }}$ observation),

$\mathrm{k}=$ last time of germination.

$G R I=\frac{N_{1}}{T_{1}}+\frac{N_{2}}{T_{2}}+\frac{N_{3}}{T_{3}}+\cdots+\frac{N_{n}}{T_{n}}$

Where;

$\mathrm{N} 1, \mathrm{~N} 2, \mathrm{~N} 3, \ldots . ., \mathrm{Nn}$ are the number of germinated seeds observed at a time (days) T1, T2, T3, ..., Tn after sowing (not accumulated/cumulative number, but the number of seeds that germinated at the specific time).

$M D G=\frac{\text { Final germination percentage }}{\text { Total number of days }}$

\section{Statistical analysis}

Data were subjected to Analysis of Variance (ANOVA) using SAS Package version 9.1. Percentage values were arcsine transformed as appropriate before subjecting them to ANOVA. The Least Significant Difference Test (LSD) at a probability of $5 \%$ was used to compare means.

\section{Results and Discussion}

As shown in Table 1, the average fresh weight of fruit and seed of $G$. walla varied within a range of 648-822 $\mathrm{mg}$ and 65-95 $\mathrm{mg}$, respectively. The average size of a fruit was about $30.34 \mathrm{~mm}$ in length and $10.60 \mathrm{~mm}$ width (Table 2). Yellowish green colour fruit contained two tadpoles-like seeds as stated by Mohamed and Lee (2016). 
Table 1: Average length, width and fresh weight of fruits and seeds

\begin{tabular}{lccc}
\hline & Length $(\mathrm{mm})$ & Width $(\mathrm{mm})$ & Weight $(\mathrm{mg})$ \\
\hline Fruit & $30.34 \pm 5.46$ & $10.60 \pm 2.21$ & $735 \pm 87$ \\
Seed & $16.45 \pm 2.34$ & $5.01 \pm 1.24$ & $80 \pm 15$
\end{tabular}

\section{Final germination percentage}

Table 2: Effect of different concentrations of PGRs on final germination percentage

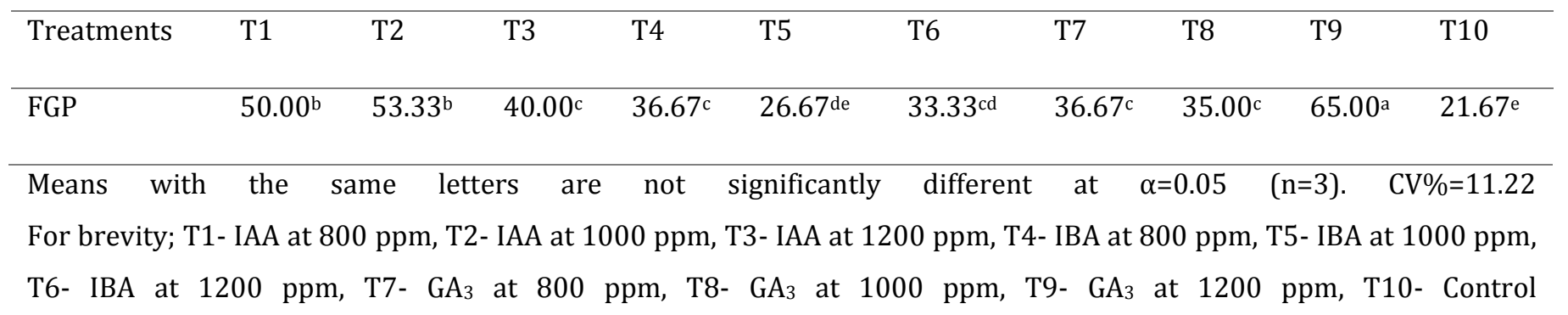



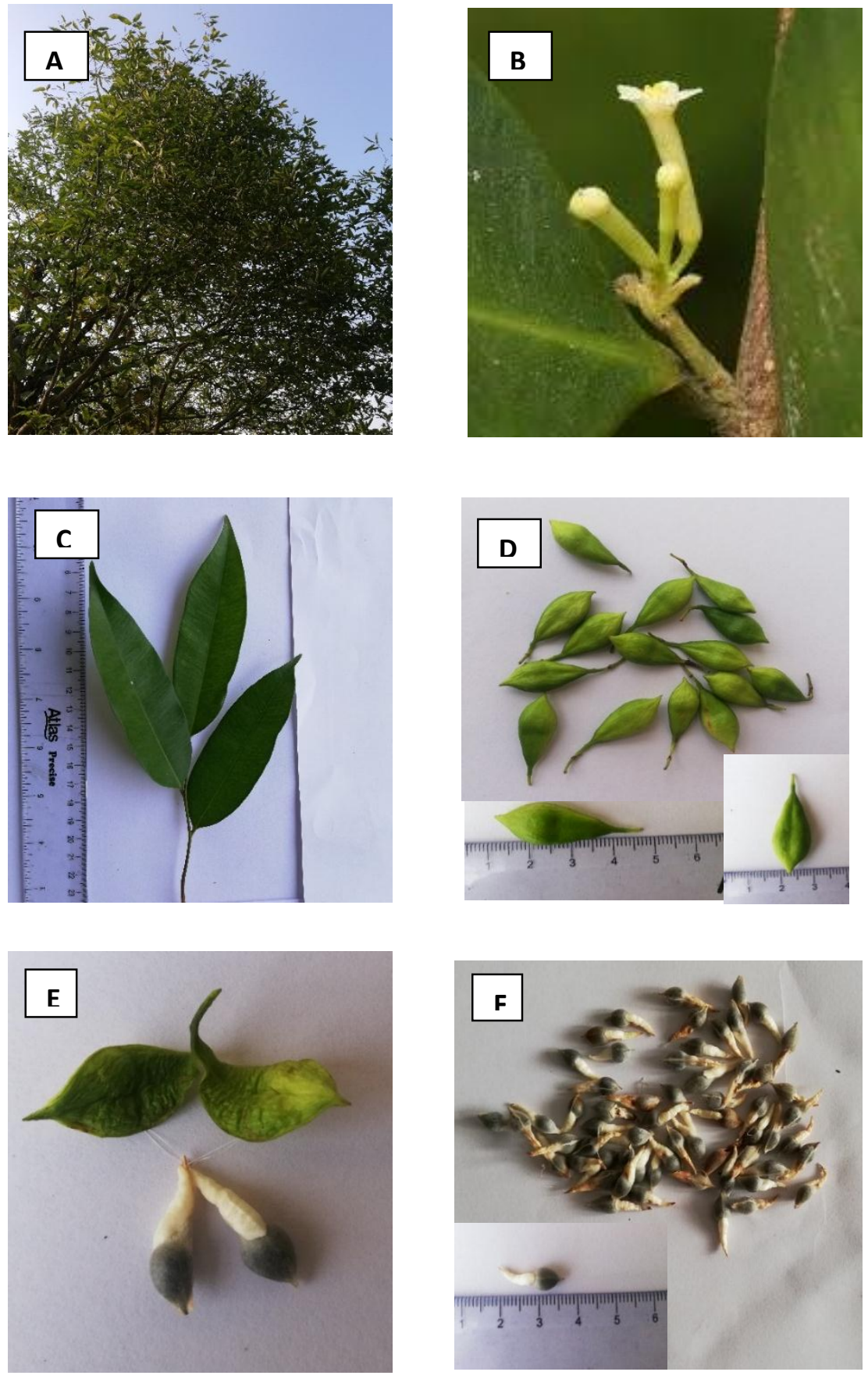

Plate1: Botanical features of G. walla. (A) Tree canopy,

(B) Flower, (C) Leaves, (D) Fruits, (E) Ruptured fruit,

(F) Seeds. 
highest final germination (65\%) was observed in $\mathrm{GA}_{3}$ at $1200 \mathrm{ppm}$, which was significantly higher than the rest and was $43.33 \%$ higher than the control (Table 2). Previous studies have also highlighted the germination promotive effect of $\mathrm{GA}_{3}$ on seed germination of Mentha piperita, Ocimum basilicum and Coriandrum sativum (Elhindi et al. 2016), Asparagus sprengeri (Dhoran and Gudadhe 2012), and Withania somnifera (Khanna et al. 2013) than IAA and IBA. In same studies, GA3 treatments reported an increase of seed germination by $52 \%, 32.6 \%, 25.3 \%, 45 \%$ and $43 \%$ respectively, when compared with respective controls.

GA3 increased seed germination in concentration-dependent manner as reported by Koyuncu (2005) for Morus nigra, Kumar et al (2014) for Coriandrum sativum and Demirsoy et al (2010) for Arbutus unedo, which was in agreement with present results as $\mathrm{GA}_{3}$ at $800 \mathrm{ppm}$ and $1000 \mathrm{ppm}$ showed significantly low germination rates of $35 \%$ and $36.67 \%$, respectively compared to 1200 ppm (Table 2). However, Das (2015) reported that $\mathrm{GA}_{3}$ at $500 \mathrm{ppm}$ could result $77 \%$ of germination in Aquillaria agallocha seeds, where control showed a germination of $49.5 \%$.

IAA at 800 ppm and 1000 ppm resulted in the second highest germination $53.33 \%$ and 50 $\%$, respectively; though, the values were not significantly different. However, these two germination values respectively $31.66 \%$ and $28.33 \%$ were higher than the control. According to Maku et al (2014), IAA was the most effective plant hormone for enhancing germination in Tetrapleura tetraptera seeds.

The PGR IBA showed comparatively higher FGP (36.67 \%) in seeds treated with 800 ppm followed by $1200 \mathrm{ppm}$ (33.33\%) and with the lowest germination of $26.67 \%$ was recorded in 1000 ppm. However, the values of FGP of all IBA concentrations were higher than that of the control (21.67\%). According to Elhindi et al (2016), IBA treatments were less effective than IAA and other plant growth regulators such as NAA, and GA3 for Mentha piperita, Ocimum basilicum, Coriandrum sativum seeds. Dhoran and Gudadhe (2012) also reported similar results with Asparagus sprengeri. 


\section{Mean germination time}

Table 3: Effect of different concentrations of PGRs on mean germination time

\begin{tabular}{llllllllllll}
\hline Treatments & T1 & T2 & T3 & T4 & T5 & T6 & T7 & T8 & T9 & T10 \\
\hline MGT & $40.05^{\text {cd }}$ & $38.27^{\mathrm{d}}$ & $39.41^{\mathrm{cd}}$ & $42.35^{\mathrm{ab}}$ & $38.63^{\mathrm{d}}$ & $43.20^{\mathrm{a}}$ & $35.53^{\mathrm{e}}$ & $34.96^{\mathrm{e}}$ & $34.94^{\mathrm{e}}$ & $40.82^{\mathrm{bc}}$ \\
\hline Means with & the same letters are & not significantly & different at & $\alpha=0.05$ & $(\mathrm{n}=3)$. & $\mathrm{CV} \%=11.22$
\end{tabular}

For brevity; T1- IAA at 800 ppm, T2- IAA at 1000 ppm, T3- IAA at 1200 ppm, T4- IBA at 800 ppm, T5- IBA at 1000 ppm, T6- IBA at 1200 ppm, T7- GA3 at 800 ppm, T8- GA3 at 1000 ppm, T9- GA3 at 1200 ppm, T10-Control

Generally, the lower mean of germination time indicate a faster germination of seeds. The lowest MGT value (34.94 days) was recorded in $\mathrm{GA}_{3}$ at $1200 \mathrm{ppm}$ followed by 1000 ppm (34.96 days) and 800 ppm (35.53 days) (Table 3). However, three MGT values were not significantly different. According to the Elhindi et al. (2016), when compared with auxins (IAA and IBA), GA3 boosted early germination of Mentha piperita and Ocimum basilicum seeds. Asparagus sprengeri seeds also showed early germination with $\mathrm{GA}_{3}$ (Dhoran and Gudadhe 2012). The highest MGT value of 43.20 days was recorded with IBA at 1200 ppm, while IBA at 800 ppm and 1000 ppm resulted in MGT of 42.35 and 38.63 days respectively and MGT values of all IBA concentrations were significant to MGT values of $\mathrm{GA} 3$ (Table 3).

\section{Mean daily germination}

Table 4: Effect of different concentrations of PGRs on mean daily germination

\begin{tabular}{lllllllllll}
\hline Treatments & T1 & T2 & T3 & T4 & T5 & T6 & T7 & T8 & T9 & T10 \\
\hline MDG & $0.94^{\mathrm{b}}$ & $1.01^{\mathrm{b}}$ & $0.75^{\mathrm{c}}$ & $0.69^{\mathrm{c}}$ & $0.50^{\mathrm{de}}$ & $0.63^{\mathrm{cd}}$ & $0.70^{\mathrm{c}}$ & $0.66^{\mathrm{c}}$ & $1.23^{\mathrm{a}}$ & $0.41^{\mathrm{e}}$
\end{tabular}

Means with the same letters are not significantly different at $\alpha=0.05(\mathrm{n}=3)$. CV\%=1.91 For brevity; T1- IAA at 800 ppm, T2- IAA at 1000 ppm, T3- IAA at 1200 ppm, T4- IBA at 800 ppm, T5- IBA at 1000 ppm, T6- IBA at 1200 ppm, T7- GA3 at 800 ppm, T8- $\mathrm{GA}_{3}$ at $1000 \mathrm{ppm}, \quad \mathrm{T} 9-\mathrm{GA}_{3}$ at $1200 \mathrm{ppm}, \mathrm{T} 10-$ Control 
The highest MDG value of $1.23 \%$ was recorded in $\mathrm{GA}_{3}$ at $1200 \mathrm{ppm}$, which was significantly different from all the other treatments.
The second highest MDG value of $1.01 \%$ was recorded in IAA at 1000 ppm followed by IAA at 800 ppm (0.94\%) (Table 4).

\section{Germination rate index}

Table 5: Effect of different concentrations of PGRs on germination rate index

\begin{tabular}{lllllllllll}
\hline Treatments & T1 & T2 & T3 & T4 & T5 & T6 & T7 & T8 & T9 & T10 \\
\hline GRI & $0.26^{\mathrm{b}}$ & $0.29^{\mathrm{b}}$ & $0.21^{\mathrm{c}}$ & $0.18^{\mathrm{cd}}$ & $0.15^{\mathrm{de}}$ & $0.16^{\mathrm{d}}$ & $0.21^{\mathrm{c}}$ & $0.20^{\mathrm{c}}$ & $0.39^{\mathrm{a}}$ & $0.11^{\mathrm{e}}$
\end{tabular}

Means with the same letters are not significantly different at $\alpha=0.05 \quad(n=3)$. CV\%=10.54 For brevity; T1- IAA at 800 ppm, T2- IAA at 1000 ppm, T3- IAA at 1200 ppm, T4- IBA at 800 ppm, T5- IBA at 1000 ppm, T6- IBA at 1200 ppm, T7- GA3 at 800 ppm, T8- GA3 at 1000 ppm, T9- GA3 at 1200 ppm, T10- Control

Germination rate index values indicate the number of seeds germinated per day, thus higher GRI values indicate higher and faster germination. The GRI value of 0.39 observed in $\mathrm{GA}_{3}$ at 1200 ppm was significantly higher Average time taken to start germination than any of the other treatments. The second highest GRI value of 0.29 was recorded in IAA at 1000 ppm followed by IAA at 800 ppm (0.26) (Table 5).

Table 6: Average time taken to start germination

\begin{tabular}{lcccccccccc}
\hline Treatments & T1 & T2 & T3 & T4 & T5 & T6 & T7 & T8 & T9 & T10 \\
\hline $\begin{array}{l}\text { Average } \\
\text { time (days) }\end{array}$ & 30 & 28 & 28 & 31 & 28 & 34 & 27 & 27 & 24 & 32
\end{tabular}

Means with the same letters within each column are not significantly different at $\alpha=0.05$ (n=3)For brevity; T1- IAA at $800 \mathrm{ppm}, \mathrm{T} 2-$ IAA at $1000 \mathrm{ppm}, \mathrm{T} 3-$ IAA at $1200 \mathrm{ppm}, \mathrm{T} 4-$ IBA at $800 \mathrm{ppm}$, T5- IBA at $1000 \mathrm{ppm}$, T6- IBA at 1200 ppm, T7- GA 3 at 800 ppm, T8- GA3 at 1000 ppm, T9- GA3 at 1200 ppm, T10-Control

The Table 7 presents the average time taken to start germination of $G$. walla seeds. The lowest time (24 days) was recorded with GA3 at $1200 \mathrm{ppm}$ followed by $\mathrm{GA}_{3}$ at $800 \mathrm{ppm}$ and 1000 ppm (27 days). The highest time (34 days) was taken by IBA at 1200 ppm, while IBA at 800 ppm and 1000 ppm showed 31 and Sri Lankan Journal of Agriculture and Ecosystems, 2(2):56-69, 2020 
28 days, respectively. In the case of IAA, the lowest time (28 days) was observed at 1000 ppm and 1200 ppm, while IAA at 800 ppm it was observed in 30 days.

The seed germination capacity of a species is dependent upon many factors including abiotic and reproductive such as phenology, pollination, and fertilization (He et al. 2005). Tabin and Shrivastava (2014) stated that despite the recalcitrant nature, the species of Aquilaria could regenerate freely under natural conditions in the forest probably due to availability of necessary moisture and light under the shaded canopy, which enhance seed germination. Accordingly, the fleshy covering of Aquilaria fruits also provides some moisture ensuring the survival of seeds until commencing the germination. According to Soehartono and Newton (2001), natural regeneration of Aquilaria is moderately higher though seed productions and dispersion under natural habitats are poor as stated by He et al. (2005). The present study also noticed that despite the recalcitrant nature, $G$. walla was enabling to regenerate through seeds under natural conditions, if ample moisture and shade is available as in rain forests. Due to continuous metabolism of recalcitrant seeds (Tabin and Shrivastava 2014), viability is lost when the moisture content drops below a certain critical level before the initiation of germination. Therefore, in the present study, measures were taken to use fresh seeds for the PGRs treatments to ensure adequate germinability of seeds.

A wide range of applications of PGRs is found in Agriculture and Forestry. GA3 is known for its ability to break dormancy and enhance seed germination (Bentsink and Koornneef 2008; Finkelstein et al. 2008). GA3 is involved in increasing the expansion of embryonic cell and inducing the hydrolytic enzymes that weaken the tissues surrounding the radicle to overcome the mechanical resistance due to the seed coat. In addition, GA3, mobilizes the seed storage reservoirs (Miransari and Smith 2014; Rami and Patel 2014). In the present study, GA3 at 1200 ppm showed significantly higher germination percentage as well as fastest germination (Table 2, 4 and 5). This might be attributed to the functions of GA3 that leads to gradual softening of seed coat facilitating the respiration of seeds, uptake oxygen and water easily, and to protrude the radicle easily into the ground.

The hormone auxin is important in regulating several aspects of growth and development of plants through the transport inhibitor response1 (TIR1)/Additional $\mathrm{F}$ box protein (AFB)-Aux/indole-3-acetic acid (IAA) -AUXIN RESPONSE FACTOR (ARF) signalling system 
(Chapman and Estelle 2009; Vanneste and Friml 2009). Auxins enhance seed germination by involving the activities of different enzymes and may increase the cell growth and development. Furthermore, auxins enhance the rate of metabolism during germination and enhance the cell elongation. The promoting effect of auxins on germination may be attributed to their indirect effect through changes in the membrane permeability and solubilization of carbohydrates through the synthesis of different enzymes responsible for promoting effects and production of some precursors needed for germination (Venkatesh et al. 2000). In the present study, higher germination percentage showed in IAA at 1000 ppm (53.33\%) followed by IAA at 800 ppm (50 \%) might be due to the above activities of auxin (Table 2).

\section{Conclusion}

$\mathrm{GA}_{3}$ at $1200 \mathrm{ppm}$ was found to be the most effective hormone treatment for enhancing seed germination of $G$. walla. The treatment also showed the highest germination and the fastest germination. Hence, this can be recommended to enhance the germination of G. walla seeds in mass scale establishment protocols

\section{Acknowledgements}

Authors acknowledge the academic and nonacademic staff of the Department of Crop Science, Faculty of Agriculture, University of Ruhuna to make this research a success.

Conflicts of Interest: The authors declare that there are no conflicts of interest regarding the publication of this paper.

\section{References}

Abdin M J (2014) The agarwood industry: yet to utilize in Bangladesh. Int. J Econ. Manag. Sci. 3: 163-166. 10.2139/ssrn.2430055

Akter S, Islam M T, Zulkefeli M, Khan S I (2013) Agarwood production: a multidisciplinary field to be explored in Bangladesh. Int. J Pharm. Life Sci. 2: 22-32. 10.3329/ijpls.v2i1.15132.

Ali T, Hossein P, Asghar F, Salman Z, Ali Z C M (2010) The effect of different treatments on improving seed germination characteristics in medicinal species of Descurainia sophia and Plantago ovata. Afr. J Biotechnol. 965886593.

Alwis $\mathrm{H}$ N, Subasinghe $\mathrm{S} M \mathrm{C}$ U P D, Hettiarachchi D S (2016) Effect of storage time and temperature on Gyrinops walla Gaertn. seed germination. Environmental Professionals Sri Lanka 5(2): 16-24. 
Alwis W N, Subasinghe $\mathrm{S} M C \mathrm{C}$ D, Hettiarachchi D S (2019) Characterisation and variation of agarwood resins from Gyrinops walla. Tropical Forest Science 31(2): 222-229.

Aravind J, Devi S V, Radhamani J, Jacob S R, Srinivasan K (2019) The germination metrics package: a brief introduction. ICAR-National Bureau of Plant Genetic Resources, New Delhi: 46.

Bentsink L, Koornneef M (2008) Seed dormancy and germination. In: Somerville C R, Meyerowitz E M, editors. The Arabidopsis Book. Rockville, MD: American Society of Plant Biologists.

Chapman E J, Estelle M (2009) Mechanism of auxin-regulated gene expression in plants. Annu Rev Genet 43: 265-285.

Das N (2015) The effect of different presowing treatments on the germination of Aquilaria agallocha and Shorea robusta seeds in the nursery. Indian Forester 141(3): 285292. doi: $10.1156 / 2015$.

Demirsoy L, Demirsoy H, Celikel G, Macit I, Ersoy B (2010) Seed treatment with $\mathrm{GA}_{3}$ or stratification enhances emergence of some strawberry tree genotypes: short communication. Horticultural Science 37(1): 34-37. doi: 10.17221/28/2009-hortsci.
Dhoran V S, Gudadhe S P (2012) Effect of plant growth regulators on seed germination and seedling vigour in Asparagus sprengeri. International Research Journal of Biological Sciences 1(7): 6-10.

Elhindi K M, Dewir Y H, Asrar A W, AbdelSalam E, El-Din A S, Ali M (2016) Improvement of seed germination in three medicinal plant species by plant growth regulators. Horticultural Science 51(7): 887891. doi: 10.21273/hortsci.51.7.887.

Finkelstein R, Reeves W, Ariizumi T, Steber C (2008) Molecular aspects of seed dormancy. Annu Rev Plant Biol 59: 387-415.

Gholami H, Farhadi R, Rahimi M, Zeinalikharaji A, Askari A (2013) Effect of growth hormones on physiology characteristics and essential oil of basil under drought stress condition. J Amer Sci 96163.

Guney K, Cetin M, Guney K B, Melekoglu A (2017) The Effects of some hormone applications on Lilium martagon L. germination and morphological characters. Pol J Environ Stud 26(6): 2533-2538. DOI: 10.15244/pjoes/70895.

Han C, Yang P (2015). Studies on the molecular mechanisms of seed germination. Proteomics 15: 1671-1679. doi: 10.1002/pmic.201400375.

He M L, Qi S Y, Hu L J (2005) Rapid in vitro propagation of medicinally important 
Aquilaria agallocha. Journal of Zhejiang University SCIENCE 6B (8): 849-852.

Khanna P K, Kumar A, Chandra R, Verma V (2013) Germination behaviour of seeds of Withania somnifera (L.) dunal: a high value medicinal plant. Physiology and Molecular Biology of Plants 19(3): 449-454. doi: 10.1007/s12298-013-0169-3.

Koyuncu F (2005) Breaking seed dormancy in black mulberry (Morus nigra L.) by cold stratification and exogenous application of gibberellic acid. ACTA Biologica Cracoviensia 2: 23-26.

Kumar M, Agnihotri R K, Vamil R, Sharma R (2014) Effect of phytohormones on seed germination and seedling growth of Coriandrum sativum L. Pakistan Journal of Biological Sciences 17(4): 594-596. doi: 10.3923/pjbs.2014.594.596.

Liu Y, Chen H, Yang Y, Zhang Z, Wei J, Meng H (2013) Whole-tree agarwood inducing technique: an efficient novel technique for producing high-quality agarwood in cultivated Aquilaria sinensis trees. Molecules 18: 30863106. 10.3390/molecules18033086.

Maku J O, Gbadamosi A E, Oke S A (2014) Effect of some growth hormones on seed germination and seedling growth of Tetrapleura tetraptera (Thaub). International
Journal of Plant Research 4(1): 36-42. doi: 10.5923/j.plant.20140401.07.

Miransari M, Smith D L (2014) Plant hormones and seed germination. Environmental and Experimental Botany 99: 110-121.

doi: 10.1016/j.envexpbot.2013.11.005.

Mohamed R, Lee S Y (2016) Agarwood: science behind the fragrance. Agarwood, Tropical Forestry 1: 167. doi: 10.1007/978981-10-0833-7.

Rami E, Patel I (2014) Effect of plant growth regulators on seed germination and seedling vigour index of Oroxylum indicum (L.) vent: an endangered medicinal plant. Plant Archives 14(1): 579-582.

Rojas-Are'chiga M, Aguilar K M, Golubov J, Mandujano M C (2011) Effect of gibberellic acid on germination of seeds of five species of cacti from the Chihuahuan Desert, Northern Mexico. Southwest Nat 56: 393-435. doi:10.1894/N01-DW-126.1.

Singh B, Sharma R A (2015). Plant terpenes: defence responses, phylogenetic analysis, regulation and clinical applications. 3 Biotech 5:129-151. 10.1007/s13205-014-0220-2.

Singh M, Singh K K, Badola H K (2014) Effect of temperature and plant growth regulators on seed germination response of Oroxylum 
indicuma - high value threatened medicinal plant of Sikkim Himalaya. J Plant Sci Res 1115.

Soehartono T, Newton A C (2001) Conservation and sustainable use of tropical trees in the genus Aquilaria. II. The impact of gaharu harvesting in Indonesia. Biological Conservation 97:29-41.

Subasinghe S M C U P D, Hettiarachchi D S (2015) Characterisation of agarwood type resin of Gyrinops walla Gaertn growing in selected populations in Sri Lanka. Industrial Crops and Products 69: 76-79. doi: 10.1016/j.indcrop. 2015.01.060.

Subasinghe S M C U P D, Hettiarachchi D S, Rathnamalala E (2012) Agarwood-type resin from Gyrinops walla Gaertn.: a new discovery. J Tropical Forestry and Environment 2(2): 4348. doi: 10.31357/jtfe.v2i2.594.

Subasinghe U (2013) Agarwood production of walla patta (Gyrinops walla): the tree of future. International Journal of Agricultural Science 2: 357-362. doi: 10.13140/2.1.2024. 2566.

Tabin T, Shrivastava K (2014) Factors affecting seed germination and establishment of critically endangered Aquilaria malaccensis (Thymelaeaceae). Asian Journal of Plant Science and Research 4(6): 41-46.

Unal B T, (2013) Effects of growth regulators on seed germination, seedling growth and some aspects of the metabolism of wheat under allelochemical stress. Bangladesh Journal of Botany. 42(1): 65-71.

Vanneste S, Friml J. (2009) Auxin: A trigger for change in plant development. Cell 136(6):1005-1016.

Venkatesh A, Vanangamudi M, Vanangamudi K, Parthiban K T, Ravichandran V, Vinaya Rai R S (2000) Effect of growth stimulants on seed germination and morpho-physiological attributes in pungam (Pongamia pinnata). J Tropical Forest Science 12(4): 643-649.

Vishal B, Kumar P P (2018) Regulation of seed germination and abiotic stresses by gibberallins and abscisic acids. Front. Plant $\begin{array}{llll}\text { Sci. } & 20 & \text { June }\end{array}$ https://doi.org/10.3389/fpls.2018.00838. 